\title{
Effect of Quality and Quantity of Dietary Protein on 4E-BP1 and S6K1 Phosphorylation of Brains in Aged Rats
}

\author{
Miho OHSUmI ${ }^{1}$, Fumiaki YoshizaWA ${ }^{2}$, Kazutoshi HAYASE ${ }^{3, *}$ and Hidehiko YoKogoshi ${ }^{1}$ \\ ${ }^{1}$ Laboratory of Nutritional Biochemistry, School of Food and Nutritional Sciences, COE Program in the 21st \\ Century, The University of Shizuoka, Yada, Suruga, Shizuoka 422-8526, Japan \\ ${ }^{2}$ Department of Animal Science, Utsunomiya University, Mine-machi, Utsunomiya, \\ Tochigi 321-8505, Japan \\ ${ }^{3}$ Department of Home Economics, Aichi University of Education, Kariya, Aichi 448-8542, Japan
}

(Received April 5, 2010)

\begin{abstract}
Summary We have shown that the rate of brain protein synthesis in aged rats depended on the quality and quantity of dietary protein consumed. The purpose of this study was to determine whether the quality and quantity of dietary protein affected the phosphorylation of eukaryotic initiation factor (eIF) 4E-binding protein 1 (4E-BP1) and ribosomal protein S6 kinase (S6K1) and regulated the brain protein synthesis. Two experiments were done on three groups of 24 -wk-old male rats given diets containing $20 \%$ casein, $20 \%$ gluten, or $20 \%$ gelatin (Experiment 1), and 20\% casein, 5\% casein or 0\% casein (Experiment 2) for $10 \mathrm{~d}$. The phosphorylation of S6K1 in both the cerebral cortex and cerebellum, and the phosphorylation of 4E-BP1 in the cerebral cortex declined with a decrease of quality and quantity of dietary protein. The phosphorylation of 4E-BP1 in the cerebellum did not differ among groups. The results suggest that the ingestion of a higher quality and quantity of dietary protein stimulates the phosphorylation of 4E-BP1 and S6K1 in the brain and increases the brain protein synthesis in the aged rats.
\end{abstract}

Key Words dietary protein, 4E-BP1, S6K1, protein synthesis, brain

The metabolic response to dietary proteins, age and hormonal factors includes marked changes in protein synthesis, especially in the liver, muscles and intestine (1-5). Protein synthesis in the brain is also sensitive to the alteration of dietary amino acid composition in young rats $(6,7)$.

Many investigators have reported that protein synthesis declined in specific tissues (e.g., liver or muscle) and in the whole body throughout development in mammals after weaning $(8-10)$. We demonstrated that the rate of protein synthesis in the brain decreased with age in rats after weaning (11). In many investigations, the protein synthesis and the concentrations of branched-chain amino acids in the brain have been shown to depend on the quality and quantity of dietary protein in aged rats (12-14).

In both liver (15) and skeletal muscle (16), the stimulation of protein synthesis caused by amino acids and protein was reported to be mediated by an increase in the initiation of mRNA translation. Administration of leucine in vivo enhanced muscle protein synthesis through the activation of the binding of mRNA to the $40 \mathrm{~S}$ ribosomal subunit (17). The mRNA binding step is regulated by initiation factors collectively referred to as eIF4F (18). The eIF4F initiation factors include eIF4E,

*To whom correspondence should be addressed.

E-mail: khayase@auecc.aichi-edu.ac.jp

Abbreviations: 4E-BP1, eukaryotic initiation factor 4Ebinding protein 1; GH, growth hormone; S6K1, ribosomal protein S6 kinase.
eIF4A, eIF $4 \mathrm{G}$ and eIF 3 . The most studied example of the regulation of protein synthesis occurring at the mRNA binding step is the reversible sequestration of eIF4E into an inactive complex with the eIF4E binding protein, 4EBP1. The binding site on eIF4E for 4E-BP1 overlaps with the eIF4G binding site. Thus, the binding of eIF4E to $4 \mathrm{E}-\mathrm{BP} 1$ precludes the binding of the eIF4E-mRNA complex to the $40 \mathrm{~S}$ ribosomal subunit (19). The interaction between eIF4E and 4E-BP1 is regulated by phosphorylation of 4E-BP1; specifically hyperphosphorylation prevents the binding while hypophosphorylation is permissive toward the binding. The phosphorylation of ribosomal protein S6 (rpS6) is another mechanism for the regulation of mRNA binding to $40 \mathrm{~S}$ ribosomal subunits. The rpS6 is located near the mRNA/tRNA binding site on the $40 \mathrm{~S}$ ribosomal subunit (20) and, therefore, has a potential role in selecting mRNA for the translation. The phosphorylation of $\mathrm{rpS} 6$ is mediated by a protein kinase termed S6K1 (20). The activation of S6K1 is also associated with the phosphorylation (17, 21). Anthony et al. $(16,17)$ and Yoshizawa et al. $(22)$ demonstrated that the oral administration of leucine stimulated the rates of protein synthesis in liver and skeletal muscle concomitant with increased phosphorylation of 4E-BP1 and S6K1. Overall, the available evidence suggests that amino acids such as leucine stimulate the translation initiation by enhancing eIF4F assembly as well as by activating S6K1. However, the role of the initiation phase of mRNA translation in maintaining the rates of brain protein synthesis remains unknown under physiological conditions in 
Table 1. Composition ( $\mathrm{g} / 100 \mathrm{~g}$ diet) of experimental diets.

\begin{tabular}{|c|c|c|c|c|c|}
\hline Ingredient & $20 \%$ Gelatin & $20 \%$ Gluten & $20 \%$ Casein & $5 \%$ Casein & $0 \%$ Casein \\
\hline Casein $^{1}$ & & & 20.0 & 5.0 & \\
\hline Gluten $^{1}$ & & 20.0 & & & \\
\hline Gelatin $^{1}$ & 20.0 & & & & \\
\hline Cornstarch $^{2}$ & 21.8 & 21.8 & 21.8 & 26.8 & 28.4 \\
\hline Sucrose $^{2}$ & 43.5 & 43.5 & 43.5 & 53.5 & 56.9 \\
\hline Corn oil $^{1}$ & 5.0 & 5.0 & 5.0 & 5.0 & 5.0 \\
\hline AIN-93M mineral mix $^{3}$ & 3.5 & 3.5 & 3.5 & 3.5 & 3.5 \\
\hline AIN-93VX vitamin mix $^{3}$ & 1.0 & 1.0 & 1.0 & 1.0 & 1.0 \\
\hline Cellulose $^{1}$ & 5.0 & 5.0 & 5.0 & 5.0 & 5.0 \\
\hline Choline chloride ${ }^{1}$ & 0.2 & 0.2 & 0.2 & 0.2 & 0.2 \\
\hline
\end{tabular}

\footnotetext{
${ }^{1}$ Supplied by Wako Pure Chemical Industries, Ltd., Osaka, Japan.

${ }^{2}$ Supplied by Oriental Yeast Co., Ltd., Tokyo, Japan.

${ }^{3}$ Supplied by Nihon Nosan K.K., Yokohama, Japan (41).
}

aged rats. The possible effects of 4E-BP1 and S6K1 phosphorylation on the brain protein synthesis in aged rats are of nutritional importance in understanding the role of protein nutrition in the brain function in mammals.

The purpose of our present study was to determine the mechanism by which the quality and quantity of dietary protein affect the brain protein synthesis in aged rats. Two questions were considered in the present study: 1) whether the quality and quantity of dietary protein control the phosphorylation of $4 \mathrm{E}-\mathrm{BP} 1$ in the brains and regulate the brain protein synthesis in aged rats, and 2) whether the phosphorylation of S6K1 might regulate the protein synthesis in the brains when the quality and quantity of dietary protein was manipulated. Therefore, we examined the phosphorylation of 4E-BP1 and S6K1 in the cerebral cortex and cerebellum of aged rats. Gelatin and gluten are known to be lower quality protein than casein because of a deficiency in several essential amino acids (e.g. tryptophan) in gelatin, and a deficiency in lysine in gluten, and also because of lower nitrogen retention (23). In particular, as the gelatin has less of many essential amino acids, the body weight decreased in young and aged rats fed a $20 \%$ gelatin diet $(7,13)$. Thus, in this experiment, $20 \%$ gelatin, $20 \%$ gluten and $20 \%$ casein diets were chosen to investigate the mechanism by which the quality of dietary protein altered the brain protein synthesis.

\section{MATERIALS AND METHODS}

Chemicals. The polyclonal antibodies of S6K1 and 4E-BP1 were purchased from Santa Cruz Biotechnology (CA, USA). All other reagents were purchased from Wako Pure Chemical Industries, Ltd. (Osaka, Japan).

Animals and diet. Male 24-wk-old Wistar rats (Japan SLC, Inc., Hamamatsu, Japan) were housed at $24^{\circ} \mathrm{C}$ in a room with a 12-h light/dark cycle. The rats were transferred to the experimental diets after being fed the $20 \%$ casein diet for $10 \mathrm{~d}$. The experimental diets contained $20 \%$ gelatin, $20 \%$ gluten or $20 \%$ casein (Experiment 1 , Table 1), or 0, 5 or $20 \%$ casein (Experiment 2, Table 1 ). All animals were individually housed and given free
Table 2. Time-dependent changes of phosphorylation states on 4E-BP1 and S6K1 in the cerebral cortex of rats treated with meal-feeding. ${ }^{1}$

\begin{tabular}{ccc}
\hline $\begin{array}{c}\text { Time after ingestion } \\
(\mathrm{h})\end{array}$ & $\begin{array}{c}4 \mathrm{E}-\mathrm{BP} 1 \\
(\%)^{2}\end{array}$ & $\begin{array}{c}\text { S6K1 } \\
(\%)^{3}\end{array}$ \\
\hline 0 & $24.1 \pm 3.5^{\mathrm{b}}$ & $34.3 \pm 2.2^{\mathrm{cd}}$ \\
1 & $15.7 \pm 4.0^{\mathrm{b}}$ & $26.2 \pm 3.6^{\mathrm{d}}$ \\
2 & $22.9 \pm 2.3^{\mathrm{b}}$ & $40.3 \pm 4.3^{\mathrm{c}}$ \\
3 & $49.9 \pm 2.7^{\mathrm{a}}$ & $66.0 \pm 2.3^{\mathrm{a}}$ \\
4 & $30.6 \pm 3.6^{\mathrm{b}}$ & $60.6 \pm 4.0^{\mathrm{a}}$ \\
5 & $31.2 \pm 3.1^{\mathrm{b}}$ & $49.9 \pm 1.5^{\mathrm{b}}$
\end{tabular}

\footnotetext{
${ }^{1}$ Values are mean \pm SE, $n=6$. Means with different superscript letters are significantly different $(p<0.05)$.

${ }^{2}$ Data indicate the amount of 4E-BP1 in $\gamma$-phosphorylated form, expressed as the percentage of the total $4 \mathrm{E}$ BP1.

${ }^{3}$ Data indicate the amount of S6K1 in $\gamma$-phosphorylated form, expressed as the percentage of the total S6K1.
}

access to food and water. The approval of Aichi University of Education Animal Care and Use Committee was given for our animal experiments.

Experimental design. Two experiments were done, with 18 rats being divided randomly into three groups. Yoshizawa et al. (22) reported that 4E-BP1 and S6K1 phosphorylation in the liver and skeletal muscle were affected very rapidly after feeding the test diet. In a preliminary experiment, we also demonstrated that the phosphorylation of 4E-BP1 and S6K1 in the brains increased significantly after only a 3-h feeding period of the 20\% casein diet (Table 2). Therefore, in the present study, the change in 4E-BP1 and S6K1 phosphorylation was measured after only one 3 -h feeding period of the test diet. After all rats were fed the $20 \%$ casein diet for $10 \mathrm{~d}$ (only one 3-h feeding period per day, from 9:0012:00), they were given the experimental diets for $1 \mathrm{~d}$ (only one $3-\mathrm{h}$ period). After a $3-\mathrm{h}$ feeding period, the rats were decapitated and brain regions (24) were quickly removed. In Experiment 1, the effects of the quality of dietary protein on 4E-BP1 and S6K1 phosphorylation in the cerebral cortex and cerebellum were 
Table 3. Effect of the quality of dietary protein on the phosphorylation states of 4E-BP1 and S6K1 in the brain regions of aged rats. ${ }^{1}$

\begin{tabular}{lccc}
\hline & $20 \%$ Gelatin & $20 \%$ Gluten & $20 \%$ Casein \\
\hline $\begin{array}{l}\text { Food intake }(\mathrm{g} / \mathrm{d}) \\
\text { Tissue weight }(\mathrm{g} / 100 \mathrm{~g} \text { of body weight) }\end{array}$ & $13.0 \pm 0.7$ & $14.5 \pm 0.6$ & $13.6 \pm 0.5$ \\
$\quad$ Cerebral cortex & $0.100 \pm 0.004$ & $0.110 \pm 0.005$ & $0.104 \pm 0.004$ \\
$\quad$ Cerebellum & $0.089 \pm 0.002$ & $0.087 \pm 0.003$ & $0.085 \pm 0.002$ \\
S6K1 phosphorylation $(\%)^{2}$ & $10.9 \pm 2.6^{\mathrm{b}}$ & $17.8 \pm 3.0^{\mathrm{b}}$ & $50.0 \pm 6.1^{\mathrm{a}}$ \\
$\quad$ Cerebral cortex & $14.0 \pm 3.0^{\mathrm{b}}$ & $15.4 \pm 2.3^{\mathrm{b}}$ & $54.7 \pm 3.8^{\mathrm{a}}$ \\
$\quad$ Cerebellum & $36.5 \pm 2.6^{\mathrm{b}}$ & $39.3 \pm 3.0^{\mathrm{b}}$ & $55.6 \pm 2.3^{\mathrm{a}}$
\end{tabular}

\footnotetext{
${ }^{1}$ Values are mean \pm SE, $n=6$. Means with different superscript letters are significantly different $(p<0.05)$. Final body weights were from 317 to $332 \mathrm{~g}$.

${ }^{2}$ Data indicate the amount of S6K1 in $\gamma$-phosphorylated form, expressed as the percentage of the total S6K1.

${ }^{3}$ Data indicate the amount of 4E-BP1 in $\gamma$-phosphorylated form, expressed as the percentage of the total 4E-BP1.
}

investigated. In Experiment 2, the effects of the quantity of dietary protein on 4E-BP1 and S6K1 phosphorylation in the cerebral cortex and cerebellum were determined.

Sample collection. Tissues were homogenized in 7 volumes of buffer [20 mM N-2-hydroxyethylpiperazine$N^{\prime}$-2-etanesulfonia acid (HEPES) at $\mathrm{pH} 7.4,100 \mathrm{mM}$ $\mathrm{KCl}, 0.2 \mathrm{~mm}$ EDTA, 2 mM ethylene glycol-bis- $(\beta$-aminoethyl ether)- $N, N, N^{\prime}, N^{\prime}$-tetraacetic acid (EGTA), $1 \mathrm{~mm}$ dithiothreitol, $50 \mathrm{~mm} \mathrm{NaF}, 50 \mathrm{~mm} \beta$-glycerophosphate, $0.1 \mathrm{~mm}$ phenylmethylsulfonyl fluoride, $1 \mathrm{~mm}$ benzamidine and $0.5 \mathrm{~mm}$ sodium vanadate] by the use of a Dounce homogenizer. The homogenate was centrifuged at $10,000 \times g$ for min at $4^{\circ} \mathrm{C}(15)$.

Examination of 4E-BP1 phosphorylation state. An aliquot of the $10,000 \times g$ supernatant was boiled for $10 \mathrm{~min}$ and then centrifuged at $10,000 \times \mathrm{g}$ for $30 \mathrm{~min}$ at $4^{\circ} \mathrm{C}$. The resulting supernatant was mixed with an equal volume of $2 \times$ SDS sample buffer, and the diluted sample was subjected to electrophoresis on $15 \%$ polyacrylamide gel. The samples were then subjected to a protein immunoblot analysis using 4E-BP1 polyclonal antibodies, as described previously (25).

Phosphorylation of S6K1. An aliquot of the 10,000 $\times g$ supernatant was combined with an equal volume of $2 \times$ SDS sample buffer, and the diluted sample was subjected to electrophoresis on $7.5 \%$ polyacrylamide gel. The samples were then subjected to a protein immunoblot analysis using S6K1 polyclonal antibodies, as described previously (26).

Statistical analysis. The means and SE are reported. Duncan's multiple range test was used to compare means after one-way ANOVA $(27,28)$. Differences were considered significant at $p<0.05$.

\section{RESULTS}

Effect of the quality of dietary protein on the phosphorylation of 4E-BP1 and S6K1 in the brains (Experiment 1)

The food intake and relative weights of brain regions did not differ among the three groups (Table 3). 4E-BP1
(A) Cerebral cortex

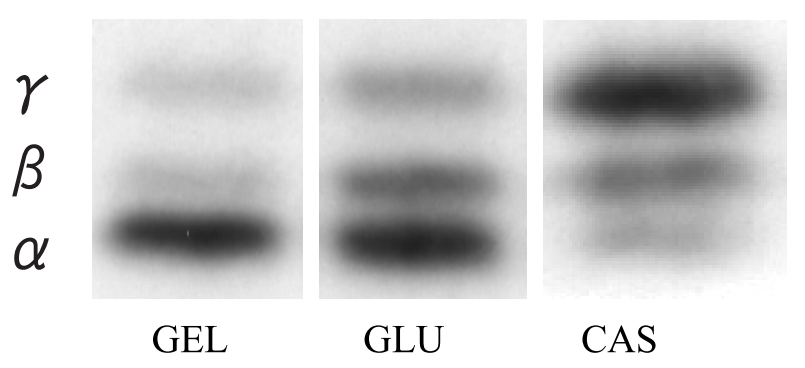

(B) Cerebellum

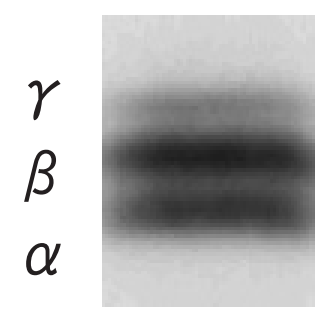

GEL

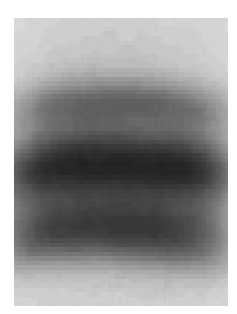

GLU

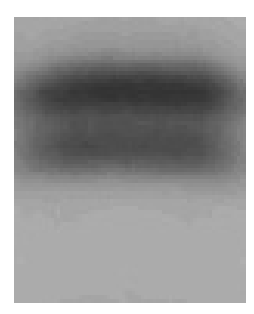

CAS
Fig. 1. Phosphorylation state of S6K1 in the cerebral cortex (A) and cerebellum (B) of aged rats fed the $20 \%$ gelatin (GEL), $20 \%$ gluten (GLU) or $20 \%$ casein (CAS) diet. Tissue extracts were subjected to SDS-polyacrylamide gel electrophoresis and the phosphorylation state of S6K1 was determined by protein immunoblot analysis. S6K1 is resolved into three bands on SDS-polyacrylamide gels, with the top band ( $\gamma$-band) corresponding to the most highly phosphorylated species. The more rapidly migrating bands are designated $\alpha$ and $\beta$. Data in the table indicate the amount of S6K1 in the $\gamma$-phosphorylated form, expressed as a proportion of the total S6K1.

and S6K1 are resolved into multiple electrophoretic forms on SDS-polyacrylamide gels, termed $\alpha, \beta, \gamma$, representing differentially phosphorylated forms of the protein. The $\gamma$ form is the most highly phosphorylated 
form and exhibits the lowest electrophoretic mobility. Therefore, in the present study, the phosphorylation and 4E-BP1 and S6K1 were expressed as the percent of $\gamma$ form in the 4E-BP1 and S6K1 respectively. The phosphorylation of S6K1 in the cerebral cortex and cerebellum was markedly lower in rats fed the $20 \%$ gelatin diet

(A) Cerebral cortex

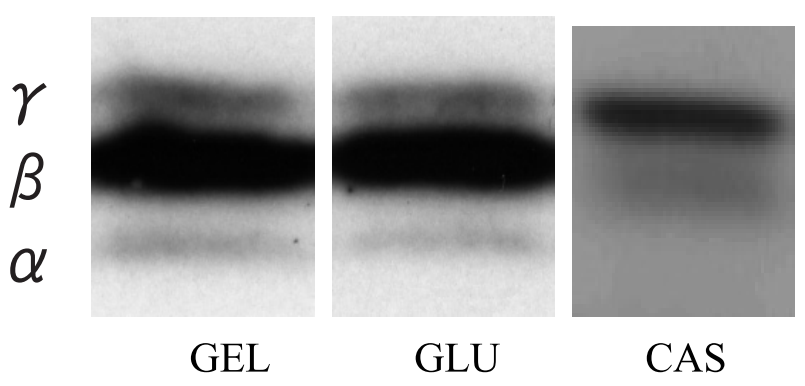

(B) Cerebellum

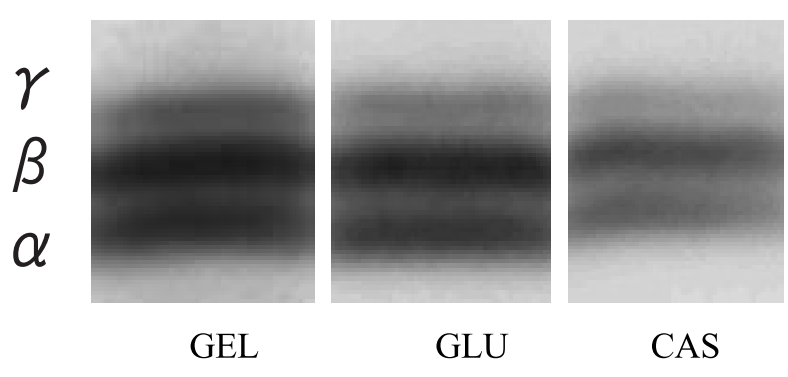

Fig. 2. Phosphorylation state of 4E-BP1 in the cerebral cortex (A) and cerebellum (B) of aged rats fed the $20 \%$ gelatin (GEL), 20\% gluten (GLU) or $20 \%$ casein (CAS) diet. 4E-BP1 was resolved into three electrophoretic forms on SDS-polyacrylamide gels. The more rapidly migrating bands are designated $\alpha$ and $\beta$, the more slowly migrating band $\gamma$. Data in the table indicate the amount of 4E-BP1 in the $\gamma$ form, expressed as the percentage of the total 4E-BP1. or $20 \%$ gluten diet than in those fed the $20 \%$ casein diet (Fig. 1, Table 3). The 4E-BP1 phosphorylation in the cerebral cortex also decreased significantly with the $20 \%$ gelatin diet or $20 \%$ gluten diet compared with the $20 \%$ casein diet. The phosphorylation of 4E-BP1 in the cerebellum was not different among the groups (Fig. 2, Table 3).

Effect of the quantity of dietary protein on the phosphorylation of 4E-BP1 and S6K1 in the brain (Experiment 2)

The food intake and relative weights of brain regions did not differ among the experimental groups (Table 4). The phosphorylation of S6K1 in the cerebral cortex and cerebellum was significantly lower in rats fed the $0 \%$ casein or $5 \%$ casein diets than in those fed the $20 \%$ casein diet (Fig. 3, Table 4). The 4E-BP1 phosphorylation in the cerebral cortex also decreased significantly with the $0 \%$ casein or $5 \%$ casein diet compared with the $20 \%$ casein diet. The phosphorylation of 4E-BP1 in the cerebellum was not affected by the dietary protein quantity (Fig. 4, Table 4).

\section{DISCUSSION}

More research concerning age-related changes in brain composition and function (e.g., nutrient metabolism), is necessary to understand the modulating effects of nutritional factors (29). Direct evidence that the supply of amino acid influenced the neuronal protein synthesis was provided by the study of Parks et al. (30). In previous studies, we found that the rate of protein synthesis in the brain decreased with the decrease in dietary protein in aged rats (12). In older rats, we also reported that the rate of protein synthesis in the brain of animals given the gluten or gelatin diets is lower than in animals given the casein diet (13). The purpose of the present experiments was to elucidate the mechanism by which dietary protein affects the brain protein synthesis in aged rats. In aged rats, we demonstrated that the higher quality and quantity of dietary protein improved the polysomal profile in the brain (31). Many investigations suggested that the polysome profile in tissues rep-

Table 4. Effect of the quantity of dietary protein on the phosphorylation states of 4E-BP1 and S6K1 in the brain regions of aged rats. ${ }^{1}$

\begin{tabular}{|c|c|c|c|}
\hline & $0 \%$ Casein & $5 \%$ Casein & 20\% Casein \\
\hline Food intake (g/d) & $13.4 \pm 0.9$ & $14.1 \pm 0.7$ & $15.1 \pm 1.1$ \\
\hline \multicolumn{4}{|c|}{ Tissue weight (g/100 $\mathrm{g}$ of body weight) } \\
\hline Cerebral cortex & $0.100 \pm 0.004$ & $0.107 \pm 0.005$ & $0.105 \pm 0.003$ \\
\hline Cerebellum & $0.085 \pm 0.003$ & $0.082 \pm 0.002$ & $0.084 \pm 0.002$ \\
\hline \multicolumn{4}{|c|}{ S6K1 phosphorylation $(\%)^{2}$} \\
\hline Cerebral cortex & $18.5 \pm 1.2^{\mathrm{b}}$ & $16.9 \pm 2.2^{\mathrm{b}}$ & $50.5 \pm 10.1^{\mathrm{a}}$ \\
\hline Cerebellum & $16.5 \pm 3.6^{\mathrm{b}}$ & $13.7 \pm 3.9^{\mathrm{b}}$ & $54.5 \pm 3.5^{\mathrm{a}}$ \\
\hline \multicolumn{4}{|c|}{ 4E-BP1 phosphorylation $(\%)^{3}$} \\
\hline Cerebral cortex & $21.5 \pm 1.2^{\mathrm{b}}$ & $37.5 \pm 2.2^{\mathrm{b}}$ & $55.4 \pm 2.5^{\mathrm{a}}$ \\
\hline Cerebellum & $38.4 \pm 7.5$ & $38.7 \pm 8.9$ & $20.8 \pm 6.8$ \\
\hline
\end{tabular}

\footnotetext{
${ }^{1}$ Values are mean \pm SE, $n=6$. Means with different superscript letters are significantly different $(p<0.05)$. Final body weights were from 318 to $333 \mathrm{~g}$.

${ }^{2}$ Data indicate the amount of S6K1 in $\gamma$-phosphorylated form, expressed as the percentage of the total S6K1.

${ }^{3}$ Data indicate the amount of 4E-BP1 in $\gamma$-phosphorylated form, expressed as the percentage of the total 4E-BP1.
} 
(A) Cerebral cortex

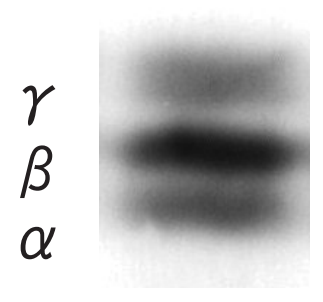

0C

\section{(B) Cerebellum}

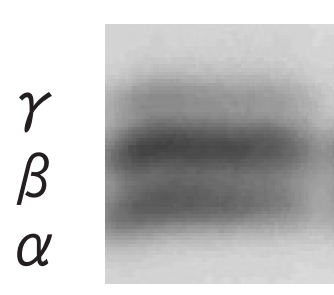

$0 \mathrm{C}$

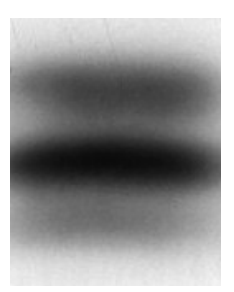

$5 \mathrm{C}$

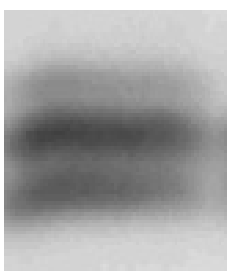

$5 \mathrm{C}$

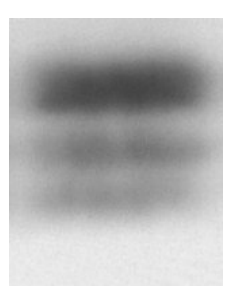

$20 \mathrm{C}$
Fig. 3. Phosphorylation state of $\mathrm{S} 6 \mathrm{~K} 1$ in the cerebral cortex (A) and cerebellum (B) of aged rats fed the $0 \%$ casein (OC), $5 \%$ casein $(5 \mathrm{C})$ or $20 \%$ casein (20C) diet.

resents the changes in the translational phase of protein synthesis $(4,5,7,32)$. However, there is little information on the mechanism by which the dietary protein affects the RNA translation in the brains of aged rats. Therefore, we hypothesized that the phosphorylation of 4E-BP1 and S6K1 in the brain regions decreased in aged rats given a lower quality or quantity of dietary protein.

S6K1 phosphorylation in the cerebral cortex and cerebellum were highest in those fed on the $20 \%$ casein diet, followed by the $20 \%$ gluten and $20 \%$ gelatin diets in Experiment 1, or by the 5\% casein and $0 \%$ casein diets in Experiment 2, in that order (Tables 3 and 4). The phosphorylation of 4E-BP1 in the cerebral cortex also decreased significantly in aged rats given a lower quality and quantity of protein. The changes in the phosphorylation of S6K1 and 4E-BP1 in the brains depended on the quality and quantity of dietary protein. Yoshizawa et al. (15) reported that the stimulation of protein synthesis caused by dietary protein was mediated by the increase in the initiation of mRNA translation in the liver. Therefore, in the present study, the quality and quantity of dietary protein may have controlled the phosphorylation of S6K1 and 4E-BP1, and been one of the factors affecting brain protein synthesis in aged rats, thus corroborating the finding of Yoshizawa et al. (15).

In our previous works $(7,14)$, we demonstrated that most essential amino acids such as branched amino acids, both in blood and in the brain, showed variations
(A) Cerebral cortex

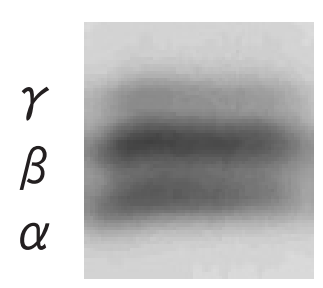

OC

(B) Cerebellum

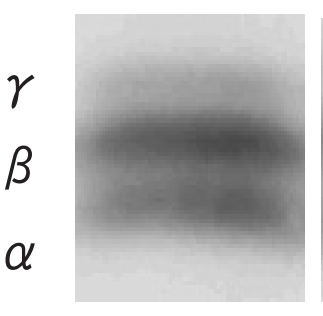

OC

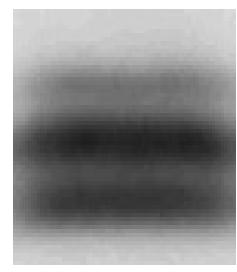

$5 \mathrm{C}$

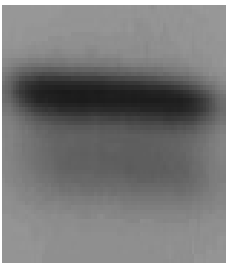

$20 \mathrm{C}$

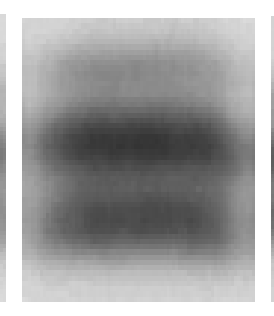

$5 \mathrm{C}$

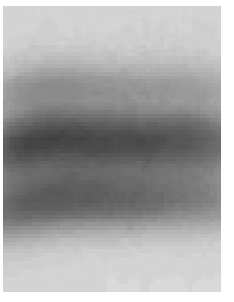

$20 \mathrm{C}$
Fig. 4. Phosphorylation state of 4E-BP1 in the cerebral cortex (A) and cerebellum (B) of aged rats fed the $0 \%$ casein (OC), $5 \%$ casein $(5 \mathrm{C}$ ) or $20 \%$ casein (20C) diet.

in accordance with their concentrations in the dietary protein of weaned and aged rats, and that the alterations in the amino acid concentrations in the blood and brain, as well as in the brain protein synthesis, resulted from changes in the quality and quantity of dietary protein. Koie et al. (33) and Lyou et al. (34) reported that the addition of lysine or methionine to a low-gluten diet or to a low-soy protein diet, respectively, increased the protein synthesis rates in the brains of aged rats. Recently, leucine has been shown to be the most potent of the amino acids in enhancing the initiation phase of mRNA translation (17). Yoshizawa et al. (35) demonstrated that leucine administration had an obvious stimulatory effect on 4E-BP1 and S6K1 phosphorylation in both liver and skeletal muscle. Our present experiment showed that, when the quality and quantity of dietary protein were high, the phosphorylation of 4E-BP1 and S6K1 in the brain was improved, which could lead to an improvement in the brain protein synthesis of aged rats. Therefore, the decrease of initiation factors of mRNA translation in the brain resulting from the lower quality or quantity of dietary protein may be due to the dietary-limiting amino acids, which were at low levels in both the blood and brain. Measurement of the role of amino acids on 4E-BP1 and S6K1 phosphorylation in the brain should be included in further studies of the effect of dietary protein on the brain protein synthesis in aged rats.

Several investigators have reported protein synthesis in visceral organs and skeletal muscle by growth hormone $(\mathrm{GH})$. Recent studies have shown that GH may affect many functions related to the central nervous system. Treatment of adult GH-deficient patients with 
human GH is reported to improve psychological well being and memory function $(36,37)$. In the previous study, we indicated that the brain protein synthesis was increased by GH in hypophysectomized aged rats, and that the plasma concentration of GH depended on the quality and quantity of dietary protein $(14,38)$. Kato (39) suggested that GH might stimulate the translational phase of protein synthesis. The effect of GH treatment on the initiation factors of mRNA translation in the brain of aged rats is another question to consider in a further study.

In the cerebellum, the phosphorylation of 4E-BP1 was not affected by dietary protein. Thus, in the initiation phase of mRNA translation of the cerebellum, S6K1 phosphorylation, rather than 4E-BP1 phosphorylation might be regulated by the quality and quantity of dietary protein in aged rats. Tujioka et al. (40) reported that the ingestion of a lower quality and quantity of dietary protein decreased the concentration and mRNA level of nerve growth factor in the brain of young rats. In the present study, we did not determine the mRNA level in the brain regions. This is another possibility to consider in further studies of the effect of dietary protein on brain protein metabolism in aged rats. On the other hand, whether leucine or GH improves the phosphorylation of 4E-BP1 in not only the cerebral cortex but also the cerebllum remains unknown. Therefore, as mentioned above, the effects of leucine and GH on 4EBP1 and S6K1 phosphorylation in the cerebral cortex and cerebellum should be determined in detail in further studies.

These results suggest that the ingestion of a higher quality and quantity of dietary protein increases the phosphorylation of 4E-BP1 and S6K1 in aged rats, and that the 4E-BP1 and S6K1 phosphorylation are at least partly related to the mechanism by which the dietary protein affects brain protein synthesis in aged rats.

\section{Acknowledgments}

This work was supported in part by a grant from the Ministry of Education, Culture, Sports, Science and Technology, Japan (No. 20500706).

\section{REFERENCES}

1) Goldspink DF, Lewis SEM, Kelly FJ. 1984. Protein synthesis during the developmental growth of the small and large intestine of the rat. Biochem J 21 7: 527-534.

2) Lewis SEM, Kelly FJ, Goldspink DF. 1984. Pre- and postnatal growth and protein turnover in smooth muscle, heart and slow- and fast-twitch skeletal muscles of the rat. Biochem J 217: 517-526.

3) Millward DJ, Garlick PJ, Nnanyelugo DO, Waterlow JC. 1976. The relative importance of muscle protein synthesis and breakdown in the regulation of muscle mass. Biochem J 156: 185-188.

4) Symmons RA, Maquire EJ, Rogers QR. 1972. Effect of dietary protein and feeding schedule on hepatic polysome pattern in the rat. J Nutr 102: 639-646.

5) Yokogoshi H, Sakuma Y, Yoshida A. 1980. Effect of dietary protein quality and quantity on hepatic polyribosome profiles in rats. J Nutr 110: 1347-1353.
6) Beverly JL III, Gietzen DW, Rogers QR. 1991. Protein synthesis in the prepyriform cortex: effects on intake of an amino acid-imbalanced diet by Sprague-Dawley rats. J Nutr 121: 754-761.

7) Yokogoshi H, Hayase K, Yoshida A. 1992. The quality and quantity of dietary protein affect brain protein synthesis in rats. J Nutr 122: 2210-2217.

8) Attaix D, Aurosseau E, Bayle G, Rosolowska-Huszcz D, Arnal M. 1988. Respective influences of age and weaning on skeletal and visceral muscle protein synthesis in the lamb. Biochem J 256: 791-795.

9) Goldspink DF, Kelly FJ. 1984. Protein turnover and growth in the whole body, liver and kidney of the rat from the foetus to senility. Biochem J 217: 507-516.

10) Waterlow JC, Garlick PJ, Millward DJ. 1978. Protein Turnover in Mammalian Tissues and in the Whole Body, p 529-594. North-Holland, Amsterdam.

11) Hayase K, Yokogoshi H. 1994. Age affects brain protein synthesis in rats. J Nutr 124: 683-688.

12) Hayase K, Koie M, Yokogoshi H. 1998. The quantity of dietary protein affects brain protein synthesis rate in aged rats. J Nutr 128: 1533-1536.

13) Koie M, Tanaka M, Hayase K, Yoshida A, Yokogoshi H. 1999. Effect of dietary protein quality on the brain protein synthesis rate in aged rats. J Nutr Sci Vitaminol 45: 481-489.

14) Ohsumi M, Shi $X$, Tuchiya T, Tujioka K, Lyou S, Hayase K, Yokogoshi H. 2007. The role of growth hormone and amino acids on brain protein synthesis in aged rats given proteins of different quantity and quality. Amino Acids 32: 247-253.

15) Yoshizawa F, Kimball SR, Vary TC, Jefferson LS. 1998. Effect of dietary protein on translation initiation in rat skeletal muscle and liver. Am J Physiol 275: E814E820.

16) Anthony JC, Gautsch Anthony T, Kimball SR, Vary TC, Jefferson LS. 2000. Orally administered leucine stimulates protein synthesis in skeletal muscle of postabsorptive rats association with increased eIF $4 \mathrm{~F}$ formation. $J$ Nutr 130: 139-145.

17) Anthony JC, Yoshizawa F, Gautsch Anthony T, Vary TC, Jefferson LS, Kimball SR. 2000. Leucine stimulates translation in skeletal muscle of postabsorptive rats via a rapamycin-sensitive pathway. J Nutr 130: 24132419.

18) Raught B, Gingrans A-C, Sonenberg N. 2000. Regulation of ribosomal recruitment in eukaryotes. In: Translational Control of Gene Expression (Sonenberg N, Hershey JWB, Mathews MB, eds), p 245-293. Cold Spring Harbor Laboratory Press, Cold Springer Harbor, New York.

19) Ptushina M, von der Haar T, Karim MM, Hughes JMX, McCarthy JEG. 1999. Repressor binding to a dorsal regulatory site traps human eIF4E in a high cap-affinity state. EMBO J 18: 4068-4075.

20) Fumagalli S, Thomas G. 2000. S6 phosphorylation and signal transduction. In: Translational Control of Gene Expression (Sonenberg N, Hershey JWB, Mathews MB, eds), p 695-717. Cold Spring Harbor Laboratory Press, Cold Springer Harbor, New York.

21) Anthony JC, Gautsch Anthony T, Kimball SR, Jefferson LS. 2001. Signaling pathways involved in translational control of protein synthesis in skeletal muscle by leucine. J Nutr 131: 856S-860S.

22) Yoshizawa F, Sekizawa H, Hirayama, S, Hatakeyama A, 
Nagasawa T, Sugahara K. 2001. Time course of leucineinduced 4E-BP1 and S6K1 phosphorylation in the liver and skeletal muscle of rats. J Nutr Sci Vitaminol 47: 311-315.

23) Steele RD, Harper AE. 1990. Proteins and amino acids. In: Present Knowledge in Nutrition (Brown ML, ed), 6th ed, p 67-79. International Life Sciences Institute, Nutrition Foundation, Washington DC.

24) Reinstein DK, Isaacson RI, Dunn AJ. 1979. Regional change in 2-deoxyglucose uptake after neocortical and hippocampal destruction. Brain Res 175: 392-397.

25) Kimball SR, Juranski CV, Lawrence JC, Jefferson LS. 1997. Insulin stimulates protein synthesis in skeletal muscle by enhancing the association of eIF-4E and eIF4G. Am J Physiol 272: C754-759.

26) Kimball SR, Horetsky RL, Jefferson LS. 1998. Signal transduction pathway involved in the regulation of protein synthesis by insulin in L6 myoblasts. Am J Physiol 274: C221-228.

27) Snedecor GW, Cochran WG. 1967. Statistical Methods, 6th ed, p 135-171. Iowa State University Press, Ames.

28) Duncan DB. 1955. Multiple range and multiple F tests. Biometrics 11: 1-42.

29) Smiciklas-Wright H. 1990. Aging. In: Present Knowledge in Nutrition (Brown ML, ed), 6th ed, p 333-340. International Life Sciences Institute, Nutrition Foundation, Washington DC.

30) Parks JM, Ames A III, Nesbett FB. 1976. Protein synthesis in central nervous tissues: studies on in vitro retina. J Neurochem 27: 987-997.

31) Hirano E, Lyou S, Tujioka K, Tanaka M, Hayase K, Okuyama S, Yokogoshi H. 2002. Effects of quantity and quality of dietary protein on the brain polysome profile in aged rats. Biosci Biotechnol Biochem 66: 351-355.

32) Siegel FL, Aoki K, Colwell RE. 1971. Polyribosomal disaggregation and cell-free protein synthesis in preparation from cerebral cortex of hyperphenylalaninemic rats. J Neurochem 27: 987-997.

33) Koie M, Tanaka M, Hayase K, Yokogoshi H. 2000.
Effects of adding dietary lysine to a low gluten diet on the brain protein synthesis rate in aged rats. Biosci Biotechnol Biochem 64: 1466-1471.

34) Lyou S, Tujioka K, Hirano E, Mawatari Y, Hayase K, Okuyama S, Yokogoshi H. 2002. Effect of adding dietary methionine to a low soy protein diet on the brain protein synthesis rate in ovariectomized female rats. Nutr Neurosci 7: 185-190.

35) Yoshizawa F, Sekizawa H, Hirayama S, Yamazaki Y, Nagasawa T, Sugahara K. 2004. Tissue-specific regulation of 4E-BP1 and S6K1 phosphorylation by $\alpha$-ketoisocaproate. J Nutr Sci Vitaminol 50: 56-60.

36) Deijen JB, de Boer H, van der Veen EA. 1998. Cognitive changes during growth hormone replacement in adult men. Psychoneuroendocrinology 23: 45-55.

37) Gibney J, Wallace JD, Spinks T, Schnorr L, Ranicar A, Cuneo RC, Lockhart S, Burnand KG, Salomon F, Sonksen PH, Russel-Jones D. 1999. The effects of 10 years of recombinant human growth hormone (GH) in adult GH-deficient patients. J Clin Endocrinol Metab 84: 2596-2602.

38) Ohsumi M, Tujioka K, Hayase K, Nagata S, Yokogoshi H. 2008. The growth hormone affects the brain protein synthesis rate in hypophysectomized aged rats. J Nutr Sci Vitaminol 54: 76-81.

39) Kato H. 2002. Molecular biology of protein metabolism. In: Molecular Nutrition (Kakinuma J, ed), p 50-64. Koseikan, Tokyo.

40) Tujioka K, Shi X, Ohsumi M, Tuchiya T, Hayase K, Uchida T, Ikeda S, Morishita A, Yokogoshi H. 2009. Effect of quantity and quality of dietary protein on choline acetyltransferase and nerve growth factor, and their mRNAs in the cerebral cortex and hippocampus of rats. Amino Acids 36: 13-19.

41) American Institute of Nutrition. 1993. AIN-93 purified diets for laboratory rodents: final Report of the American Institute of Nutrition Ad Hoc Writing Committee on the reformulation of the AIN 76A rodent diet. J Nutr 123: 1939-1951. 